\begin{tabular}{c} 
Volume and Issues Obtainable at Center for Sustainability Research and Consultancy \\
Journal of Accounting and Finance in Emerging Economies \\
ISSN: 2519-0318 ISSN (E) 2518-8488 \\
Volume 1: Issue 1 June 2015 \\
CSRᄃ \\
Journal homepage: www.publishing.globalcsrc.org/jafee \\
\hline
\end{tabular}

\title{
Analyzing the Determinants of Cash Holdings of Small and Medium-Sized Entities in Nigeria
}

\author{
${ }^{1 *}$ Muhammad Musa Tsagem, ${ }^{2}$ Norhani Aripin, ${ }^{3}$ Rokiah Ishak \\ ${ }^{1} \mathrm{PhD}$ Scholar, School of Accountancy, College of Business, Universiti Utara Malaysia. \\ musatsagem@gmail.com \\ ${ }^{2}$ Associate Professor, School of Accountancy, College of Business, Universiti Utara Malaysia. \\ norhani@uum.edu.my \\ ${ }^{3}$ Senior Lecturer, School of Accountancy, College of Business, Universiti Utara Malaysia. \\ rokiah@uum.edu.my
}

\begin{abstract}
ARTICLE DETAILS
History

Revised Format May 2015

Available Online June 2015

Keywords
Cash Holdings;
Cash Conversion Cycle;
Profitability;
Account Receivables period;
Small and Medium-sized
Entities.

JEL Classification:

L25, L29

ABSTRACT

Purpose: This paper aims to report the results of an empirical investigation on the determinants of the cash holdings for small and medium-sized entities. The paper considers the different explanatory factors of SMEs cash holdings for a sample of Nigerian SMEs. SMEs are springboard of the Nigerian economy contributing to gross domestic product, employment generation and industrialization.

Methodology: the study employed panel data regression analysis using secondary data on a sample of 311 Nigerian SMEs for the period 2007 2013.

Result: The finding which is robust of endogeneity shows statistically significant association between cash conversion cycle, account receivables period, return on assets and board size with SMEs cash holdings. Also found a significant relationship between cash holdings with firm size, leverage, growth opportunities and firm age.

Implication: Thus, the result of the study indicates that Nigerian SMEs with shorter cash conversion cycle and low growth opportunities hold more cash. Similarly, SMEs with small board of directors accumulate large cash balance. Further, SMEs with higher profitability keep large cash balance. This study contributes to existing literature on the determinants of SMEs cash holdings more specifically in developing economies. However, this study is limited to non-financial and non-service SMEs. Future study should extend the investigation to financial and services firms. Similarly the structure of the paper and scope of further study may be extended to include the effects of more corporate governance mechanisms.
\end{abstract}

(C) 2015 The authors, under a Creative Commons Attribution-

NonCommercial 4.0

Corresponding author email address: musatsagem@gmail.com

Recommended citation: Tsagem, M. M., Aripin, N., \& Ishak, R. (2015). Analyzing the Determinants of Cash Holdings of Small and Medium-Sized Entities in Nigeria. Journal of Accounting and Finance in Emerging Economies, 1 (1) 31- 40. DOI: https://doi.org/10.26710/jafee.v1i1.62 


\section{Introduction}

Firm's cash holding policies compose of transactional, precautionary and speculative motive referred to as the firm's demand for money in Keynesian theory. According to Opler, Pinkowitz, Stulz and Williamson, (2001) firm may carry significant level of liquid assets for variety of motives and the best recognized motive is to minimize transaction cost. A firm hold significant amount of cash to take care of everyday transactions; payment for goods and services and day to day routine payments (Gill \& Shah, 2011). Specifically, firms maintained certain cash level to pay for purchase of raw materials, payment of salaries and wages and other running expenses. Similarly, a firm can hold an amount of cash balance for precautionary reason to take care of unexpected and unforeseen cash demand. Perhaps, firm's cash requirement may vary due to increase in the price of raw materials or delay in payment by debtors or workers strike.

Further, firms keep certain level of cash balance to take advantage of any business opportunities which are out of its normal course of business. Indeed, opportunities arise such as special discount from suppliers on condition of cash payment, decline in the interest rate on borrowed fund, fall in the price of raw material. Opler et al. (2001) stressed on the two primary benefits of holding liquid assets which are transactional motive and precautionary motive. The transactional motive allows firm to finance its business transactions at low cost. On the other hand, the precautionary motive explain how firm finances its activities and investments with available liquid assets where other sources of funds are not available or are costly. Both transaction and precautionary motives are described as important determinants of firm's cash holdings (Gill \& Shah, 2011).Therefore, for smooth operations, a firm requires to maintain an optimum level of liquidity (Anjum \& Malik, 2013). Optimum cash level involves trade-off between the cost and benefits of holding cash (Afza \& Adnan, 2007). Hence, there are benefits and cost of holding certain amount of cash. Adequate cash level reduces risk of financial distress, allowed firms to pursue their investment policy and minimize cost of raising external financing or liquidating of existing assets (Ferreira \& Vilela, 2004). According to Owolabi (2012) effective cash management policy improves firm's profitability and reduces the risk of corporate failure. Similarly, Autukaite and Molay (2014) added that effective cash management reduces firm dependency on external financing and uses the available cash for further investment which enhances firm's financial flexibility. However, the cost of holding cash is the opportunity cost of the capital invested in liquid assets (Steijvers \& Niskanen, 2013; Gill \& Shah, 2011). Thus, holding large amount of cash is the forgone of potential returns to the firm.

Cash holdings refer to cash or cash equivalent readily available for investments and for distribution to stockholders (Amarjit Gill \& Shah, 2012). According to Anagnostopoulou (2012) the determinant factors of firm's cash holding are derived from firm specific characteristics, capital constraints and or corporate governance and agency consideration. The findings of the study suggest that the differences in the cash ratios are determined by their different sensitivities to capital expenditures, leverage and dividend payments.

The aim of this study is to present empirical findings on some of the determinants of SMEs cash holdings in Nigeria. Particularly, SMEs have been fully recognized as the springboard for attaining sustainable economic development all over the world and generally regarded as the driving force of economic growth, employment generation and poverty reduction (Okpara, 2011). Moreover, SMEs are generally characterised by prolong financial constraints (Fazzari \& Petersen, 1993 and Howorth et al., 2000) due to their inability to obtain financing in the long-term capital market, poor financial management and their vulnerability to risk (Baños-Caballero et al., 2010; 2012). Similarly, the prevalence of information asymmetry between SMEs and external investors affect their ability to secure external financing (Steijvers \& Niskanen, 2013). 


\section{Theoretical framework and Literature review}

In this study the framework of firm's determinants of cash holdings are explain from three different theories: First, the trade-off theory which focus on the costs and benefits of firm's cash holdings. According Opler et al. (2001) the firm's optimal level of cash can be view from the perspective of shareholders wealth maximization goal. In this perspective managers and shareholders have different view on the costs and benefits of the firm's liquid resources. For management liquid assets in the form of cash and cash equivalent reduces risk of financial distress and give managers more power in their spending and other financial decisions. However, shareholders argued that managers are more interested on precautionary motives in relation to 'free cash flow' and over investment. Based on these conflicting view management seek to maintain optimal cash level which balance costs against the benefits of holding more cash (Opler et al., 2001). The second view arises based on pecking order theory (POT) of firm's financing theory. The theory postulates that firm's cost of obtaining financing increases with its level of asymmetric information (Myers \& Majluf, 1984). The two major source of firm finance come from 'internally generated and external source' (debts and equity). According to this theory, firm's leverage (debts) ratio reacts positively to changes in the firm's operating cash flows which lead to changes in firm's cash holdings (Opler et al., 2001). The third model is free cash flow theory advanced by Jensen (1986) which assert that managers have an incentive to build up cash to increase the amount of assets under their control and to gain discretionary power over the firm investment decision. Kariuki, Namusonge and Orwa (2015) added that the available cash will permit the managers to undertake investments that the financial market is not willing to finance. In other words managers tend to hold more cash to avoid market discipline.

In addition to the three theoretical models which explain on the cash holdings decisions, previous researchers on cash holdings provide empirical evidences on the effects of the determinants on the corporate cash holdings. For example, Opler et al. (2001) investigate the corporate cash holdings determinants. The study utilizes data of US industrial firms during the period $1952-1994$. The result of the study indicates that large firms with greater access to capital market and firms with credit rating hold small amount of cash compared with small companies and firms with strong growth opportunities and riskier investment.

In 2004, Ozkan \& Ozkan investigates the empirical determinants of cash holdings of a sample of UK firms. The study utilizes a sample of 839 publicly traded UK companies during the period $1995-1999$ and their study is conducted based on the question why do firms hold large amount of cash? The finding of the study reveals that ownership of structure of a firm play a significant role in determining corporate cash holdings. Similarly, growth opportunities, cash flow, liquid assets, leverage and bank debts are found to be important determinants of UK corporate cash holdings.

A study by García-Teruel and Martínez-Solano (2008) analysed the SMEs cash holdings to identify the determining factors by using a sample of 860 Spanish SMEs during 1996-2001. Findings of the study describe that SMEs set a target cash level to which they attempt to reach. This target cash level is set higher by SMEs with more growth opportunities. Also, the study reveals that the target cash holding falls when the firm uses more bank debt or any substitutes of cash to finance its operations.

Afza and Adnan (2007) investigated the determinants of corporate cash holdings of non-financial firms in Pakistan. The study utilises data set of a sample of Pakistanis firms across industries and firm size over the period $1995-2005$. The finding of the study shows that net working capital, market-to-book ratio, dividend payment and leverage are negatively related to corporate cash holdings. However, a positive association was found between firm's cash flows and leverage with cash holdings. Gill and Shah (2012) seek to extend the work of Afza and Adnan (2007) by investigating the determinants of 
corporate cash holdings of Canadian firms. The study used a sample of 166 firms listed on Toronto Stock Exchange Market during the period 2008 - 2010. The findings of the study show that firm' cash flows, net working capital, market-to-books ratio, board size, firm size, leverage and CEO duality are significant determinants of corporate cash holdings of Canadian listed firms.

Kariuki et al. (2015) investigates the corporate cash holdings determinants of private manufacturing firms in Kenya. The study adopted cross-sectional survey design for a sample of 156 manufacturing firms. The study utilises questionnaire to obtained self-reported financial measures from the CFOs of the sample firms. The result of the study shows that growth opportunities and likelihood of financial distress are negatively associated with the corporate cash holdings. Firm leverage shows a significant positive relationship with corporate cash holdings whereas, firm size reveals a positive relationship with corporate cash holdings.

Based on the literature review above on the determinants of corporate cash holdings, the following hypotheses were developed and stated below for testing.

H1: There exists a significant negative relationship between cash conversion cycle and SMEs cash holdings.

H2: There exists a significant positive relationship between return on assets and SMEs cash holdings.

H3: There is a significant positive relationship between cash conversion efficiency and SMEs cash holdings.

H4: There exists a significant positive relationship between board size and SMEs cash holdings.

H5: There exists a significant positive relationship between firm size and SMEs cash holdings.

H6: There exists a significant positive relationship between sales growth and SMEs cash holdings.

H7: There exists a significant negative relationship between leverage and SMEs cash holdings.

H8: There exists a significant positive relationship between firm age and SMEs cash holdings.

\section{Methodology}

The study applied panel data obtained from the financial reports of 311 samples of non-financial and non-services Nigerian SMEs over the period 2007 - 2013 which give 2,177 firms-year observations. The sample SMEs cut across all the sectors of the economy except the financial and services firms. Financial and services firms are exempted from the study because they are outside the scope of the study. Similarly, samples SMEs are drawn from all the six geopolitical zones/areas of Nigeria using cluster sampling and random sampling techniques. Furthermore, some variables are not included in this study for example dividend was excluded because most of the sample SMEs are family-owned firms (Tsagem, et al., 2014).

\subsection{Study Variables and their Measurement}

To be consistent with previous studies, all the measurement of the study variables were taken from different scholars. For example, the dependent variable corporate cash holding was taken from Afza and Adnan (2007); Gill and Shah (2011); Gill and Biger (2013); Opler et al. (2001); Bokpin, Isshaq and Aboagye-Otchere (2011). The independent variables; CCC, ROA and CCE were adopted from Gill and Biger (2013); Anjum and Malik (2013); Abushammala and Sulaiman (2014) and Tsagem, Aripin and Ishak (2015).Others are BSIZE, FSIZE, LEV and FAGE adopted from Gill ansd Shah (2011); Block and Lau (2012). The summary of all the variables and their measurement are as follows:

Table 1: Measurements of Variables

\begin{tabular}{llcl}
\hline Variables & Measurement & Abbreviations & Type \\
\hline Cash Holdings & Log of Average cash & $\mathrm{CH}$ & Dependent \\
\hline
\end{tabular}




\begin{tabular}{|c|c|c|c|}
\hline Cash conversion cycle & $\begin{array}{l}\text { Account Receivables Period }+ \\
\text { Inventory Holding Period- Accounts } \\
\text { Payable Period }\end{array}$ & CCC & \\
\hline Return on Assets & $\begin{array}{l}\text { Earnings Before Interest and Tax/ } \\
\text { Total Assets' }\end{array}$ & ROA & \\
\hline $\begin{array}{l}\text { Cash Conversion } \\
\text { Efficiency }\end{array}$ & $\begin{array}{l}\text { Net Cash Flow from operating } \\
\text { activities / Sales }\end{array}$ & $\mathrm{CCE}$ & Independent \\
\hline Board Size (BSIZE) & $\begin{array}{l}\text { Number of Directors Serving on } \\
\text { Board }\end{array}$ & BSIZE & \\
\hline Firm Size(FSIZE) & Natural Logarithm of Total Assets & FSIZE & \\
\hline $\begin{array}{l}\text { Leverage } \\
\text { (LEVERAGE) }\end{array}$ & Total debt / Total Assets & LEV & \\
\hline Sales Growth & $\left(\right.$ sales $_{1}-$ sale $\left._{0}\right) /$ saleso & GROW & \\
\hline Firm Age & Number of years since incorporation & FAGE & \\
\hline
\end{tabular}

\subsection{Regression Model}

Consistent with previous studies by Opler et al. (2001); Afza and Adnan (2007); Gill and Shah (2011); Anjum and Malik (2013), the regression model of the study is stated as follows:

CHit $=\beta o+\beta_{1}$ CCCit $+\beta_{2}$ ROAit $+\beta_{3}$ CCEit $+\beta_{4}$ BSIZEit $+\beta_{5}$ FSIZEit $+\beta_{6}$ LEVit $+\beta_{7}$ SGROWPit + $\beta_{8}$ FAGEit+ €it.

\section{Results and Discussions}

This section presents the results and the discussions of the descriptive and the quantitative analysis of the variables of the study. The first part presents the descriptive statistics of the relevant aspects of the study variables. In the second, the quantitative analysis follows in the form of correlation and panel data regression analysis using STATA statistical software package.

\subsection{Descriptive Statistics}

Table 2 explores the descriptive analysis of the pooled data obtained from the financial statement of the sample SMEs over the period 2007-2013. The table describes the the standard deviation and the mean values for each of the study variable. Besides that, the table also describes the minimum and the maximum value to depict the extreme values obtained by all the variables of the study over the period of the study.

Table 2: Descriptive Statistics $(N=311 ; T=7)$

\begin{tabular}{lrrrr}
\hline Variables & Min & Max & Mean & Std. Dev. \\
\hline CH (Log) & 0.00 & 18.94 & 13.48 & 1.27 \\
CCC (days) & -597 & 385 & 2.66 & 55.41 \\
ROA & 0.00 & 2.13 & 0.15 & 0.13 \\
CCE & 0.00 & 1.00 & 0.05 & 0.09 \\
BSIZE (No.) & 2 & 11 & 4 & 1.25 \\
FSIZE (Ln) & 12.92 & 23.25 & 15.46 & 1.22 \\
SGROW & -1.00 & 35.00 & 0.36 & 1.49 \\
LEV & 0.00 & 6.16 & 0.08 & 0.21 \\
FAGE (Yrs) & 1 & 41 & 11 & 6.73 \\
\hline
\end{tabular}

Observations $=2,177$ firm-years observations. 
The dependent variable SMEs cash holding has a mean value of 13.48 indicating the percentage of cash available to Nigerian SMEs for meeting day to day operations. The minimum value for cash holdings show 0 and the maximum value is 18.94. On average the cash conversion cycle is 2.6 days for the sample Nigerian SMEs and a minimum of -597 days and maximum of 385 days. According to Abuzayed (2012) a positive cash conversion cycle indicate the number of days a firm must borrow or tie-up its capital while awaiting payment from customers whereas a negative CCC indicate the number of days a firm has received cash from sales before it must pay its trade creditors. The second determinant is profitability measured by the return on assets (ROA) which has an average of $15 \%$. For cash conversion efficiency which measures the speed at which firm converts its sales to cash and the result indicates an average of 0.05 cash conversion efficiency for the sample SMEs which shows a very low efficiency at which Nigerian SMEs are converting their sales to revenue. The board size of the sample Nigerian SMEs has an average of 4 directors on their board with a minimum of 2 and maximum of 11 members on board. Presently, compliance to Code of Corporate Governance rules is not mandatory to SMEs in Nigeria which set a minimum of eight board members to all listed companies.

Furthermore, the descriptive analyses of the remaining variables indicate that firm size is 15.46 and total sales of the study SMEs increases by 36 percent annually. The debt to total assets ratio (leverage) is 0.08 which indicate the ratio of external financing source from the total financing of the study SMEs. This shows that most of the Nigerian SMEs are relying on internal financing sources from the owners and retained earnings. Further, it indicate the level of inadequate funding from the external sources such as creditors, banks and other financial institutions which may be attributed to their level of opacity, information asymmetric and poor resources management. Lastly, the average age of the sample SMEs is 11 years which indicates high level of bankruptcy and death of SMEs during the period of the study.

\subsection{Pearson Correlation Coefficient}

The results in table 3 below revealed the correlation coefficient among the study variables. The correlation analysis reveals a significant positive association between $\mathrm{CH}$ with ROA, CCE, FSIZE, GROW and FAGE. This indicates that cash holdings of the sample SMEs is positively affected by the firm's profitability measured by ROA and CCE. Similarly, an increase in the firm size measured by natural logarithm of total assets and firm growth opportunities results to increase in the firm cash holdings. Firm age also have a significant effects on the SMEs cash holdings.

Correlation among the independent variables shows that cash conversion cycle is significantly associated with CCE, BSIZE, FSIZE, LEV and firm age. Return on assets is found to be correlated with CCE, FSIZE, LEV and firm age at 1 per cent significant level. Similarly, cash conversion efficiency reports a significant positive association with firm size, growth and leverage at $1 \%$ level, respectively.

Table 3: Pearson Correlation and Multicollinearity Test

\begin{tabular}{|c|c|c|c|c|c|c|c|c|c|c|c|}
\hline & \multicolumn{5}{|c|}{ Pearson Correlation Co } & \multirow[b]{2}{*}{ FSIZE } & \multirow[b]{2}{*}{ SGROW } & \multirow[b]{2}{*}{ LEV } & \multirow[b]{2}{*}{ FAGE } & \multicolumn{2}{|c|}{ Multicollinearity } \\
\hline & $\mathrm{CH}$ & $\mathrm{CCC}$ & ROA & CCE & BSIZE & & & & & VIF & $1 / \mathrm{VIF}$ \\
\hline $\mathrm{CH}$ & 1.00 & 0.00 & $.208 * *$ & $.163 * *$ & 0.01 & $.529 * *$ & $.091 * *$ & -0.01 & $.183^{* *}$ & & \\
\hline $\mathrm{CCC}$ & & 1.00 & -0.02 & $-.052 *$ & $.102 * *$ & $.123 * *$ & -0.02 & $-.367 * *$ & $.077 * *$ & 1.14 & 0.87 \\
\hline ROA & & & 1.00 & $.313 * *$ & -0.01 & $.234 * *$ & -0.03 & $.082 * *$ & $-.125 * *$ & 1.13 & 0.89 \\
\hline CCE & & & & 1.00 & 0.00 & $.068 * *$ & $.084 * *$ & $.191 * *$ & $-.052 *$ & 1.30 & 0.77 \\
\hline BSIZE & & & & & 1.00 & $.241 * *$ & -0.02 & 0.03 & $.075^{* *}$ & 1.04 & 0.96 \\
\hline FSIZE & & & & & & 1.00 & $.153^{* *}$ & -0.02 & $.272 * *$ & 1.44 & 0.69 \\
\hline SGROW & & & & & & & 1.00 & $.046^{*}$ & $.098 * *$ & 1.07 & 0.94 \\
\hline LEV & & & & & & & & 1.00 & 0.00 & 1.13 & 0.88 \\
\hline FAGE & & & & & & & & & 1.00 & 1.10 & 0.91 \\
\hline
\end{tabular}

** Correlation is significant at $1 \%$ and *significant at $5 \%$ level, respectively. 
In addition to the Pearson Correlation Coefficient, a multicollinearity diagnostic test in Table 3 indicates absence collinearity among the independent variables of the study. The VIF values for all the variables are less than 10 and the Tolerance values are above 0.10 (Field, 2013; Hair, Hult, Ringle \& Sarstedt, 2014; Sekaran \& Bougie, 2011). Therefore, it could be conclude that multicollinearity is not a problem in this study.

\subsection{Regression Analysis}

Table 4 presents panel data regression estimates for the 311 sample Nigeria SMEs during the period 2007 - 2013. The determinants of cash holdings considered under the two models are the same except that fixed effect model omitted board size (BSIZE) due to invariant nature of the variable overtime. To counter the effects of the omitted variable and to be consistent with previous studies by Abuzayed (2012); Mathuva (2010); Arunkumar and Radharamanan (2012), the regression was first estimated with Pooled OLS model which include all the variables of the study. The two models were estimated with robust standard errors using Modified Wald test for heteroskedasticity and Wooldridge test for Autocorrelation. Furthermore, the two models are fit with p-values of (0.000) less than 5 percent each and the R-squared value of $31.31 \%$ and $42.19 \%$ portray by the OLS regression model and fixed effects regression model respectively which indicates the variation in the cash holdings explained by the changes in the determinants.

Table 4: OLS Regression and Fixed Effects Models

\begin{tabular}{|c|c|c|c|c|c|c|c|c|}
\hline \multirow[b]{2}{*}{ Variables } & \multicolumn{3}{|c|}{ OLS Regression } & \multicolumn{5}{|c|}{ Fixed Effect Regression } \\
\hline & Coef. & Std. Err. & t-value & $\mathrm{p}$-value & Coef. & Std. Err & t-value & $\mathrm{p}$-value \\
\hline $\mathrm{CCC}$ & -0.001 & 0.000 & -2.95 & $0.003 * * *$ & -0.001 & 0.000 & -3.68 & $0.000 * * *$ \\
\hline $\mathrm{ROA}$ & 0.017 & 0.002 & 8.58 & $0.000 * * *$ & 0.008 & 0.002 & 3.59 & $0.000 * * *$ \\
\hline $\mathrm{CCE}$ & -0.423 & 0.361 & -1.15 & 0.252 & 0.425 & 0.269 & 1.58 & 0.114 \\
\hline BSIZE & -0.351 & 0.077 & -4.53 & $0.000 * * *$ & \multicolumn{4}{|c|}{ Omitted } \\
\hline FSIZE & 0.557 & 0.049 & 11.23 & $0.000 * * *$ & 0.287 & 0.034 & 8.47 & $0.000 * * *$ \\
\hline SGROW & 0.000 & 0.000 & -1.14 & 0.255 & -0.001 & 0.000 & -2.86 & $0.006^{* * *}$ \\
\hline LEV & -0.006 & 0.002 & -2.85 & $0.004 * * *$ & -0.005 & 0.002 & -2.84 & $0.005 * * *$ \\
\hline FAGE & 0.007 & 0.004 & 1.83 & $0.068^{*}$ & 0.241 & 0.011 & 21.37 & $0.000 * * *$ \\
\hline Constant & 5.221 & 0.746 & 7.00 & $0.000 * * *$ & 6.685 & 0.455 & 14.69 & $0.000 * * *$ \\
\hline R-square & & & & $31.31 \%$ & & & & $42.19 \%$ \\
\hline Prob. & & & & $0.000 * * *$ & & & & $0.000 * * *$ \\
\hline
\end{tabular}

$* * *$ Significant at $1 \%, * *$ significant at $5 \% *$ significant at $10 \%$.

The coefficients of cash conversion cycle is negative (-0.001) and significant at $1 \%$ level. This indicates that $\mathrm{CCC}$ has a negative effect on firm cash holding, that a decrease in the cash conversion period is associated with increase in the firm's cash holdings. The finding supported hypothesis 1 which predict a significant negative relationship between CCC and SMEs cash holdings and is consistent with finding of Anjum and Malik (2013). However, the finding is contrary to pecking order theory which assumes that firms with longer CCC hold more cash than firms with shorter CCC (Bigelli \& Sánchez-Vidal, 2012; Opler et al., 2001). The coefficient of return on assets is positive and highly significant. The finding support the study hypothesis 2 and is consistent with result obtained by Abushammala and Sulaiman (2014); Ogunpide, Ogunpide and Ajao (2012) which indicates that firms with higher profitability measured by ROA tends to hold more cash holdings than firms with low ROA. 
Furthermore, the finding of the study shows a significant negative relationship between cash holdings with board size of the Nigerian SMEs under the OLS regression model. This indicates that SMEs with small board hold more cash than those with large board. The finding fails to support the study hypothesis 4 which predict a positive relationship between corporate cash holdings with board size. However, the finding is consistent with results obtained by Ujunwa (2012) and Kumar and Singh (2013). Similarly, the finding is consistent with the view that small board is more effective in monitoring management and decision making and reduces free riding problem (Jensen, 1993).

The regression results of firm size, sales growth, leverage and firm age are all significant at $1 \%$ level under the fixed effect model. The positive relationship between firm size and corporate cash holdings means large firms holds more cash (Ozkan \& Ozkan, 2004) than small firms and is consistent with the view that firm size affects corporate cash policy. Firm size is tested using trade-off theory of cash holdings. The findings under the two models support the study hypothesis 5 which predict significant positive relationship between firm size and firm cash holdings. According to Ozkan and Ozkan (2004) large firms tends to holds more cash to maintain higher level and quality of operations and investment opportunities. As for growth opportunities measured by sales growth, the finding of the study under fixed effect model shows that firms with low sales growth tends to holds large amount of cash. The finding support Afza and Adnan (2007); Anjum and Malik (2013) that sales growth is a significant determinant of corporate cash holding. Similarly, the coefficients of leverage under the two models were found to be negative and highly significant at $1 \%$ level. Leverage measures the ratio of total debts to total assets and firm's financial risks. The findings support hypothesis 7 which predict negative association between leverage and firm's cash holdings and is consistent with findings by (Ozkan \& Ozkan, 2004) and the view that large cash reserve lower firm's risk of defaults and reduces financial risks (Wai \& Zhun, 2013). The findings are in variance with (Ogunpide et al., 2012) who report a positive relationship between leverage and corporate cash holdings. Lastly, the coefficients of firm age were found to be positive and significant under the two models which indicate that older firms hold large amount of cash than newly established firms. The findings support the study hypothesis 8 which predict a positive relationship between firm age and firm's cash holdings and are consistent with result obtained.

\section{Summary and Conclusion}

This study focuses on the determinants of cash holdings of a sample of 311 non-financial and nonservices Nigerian SMEs over the period of 2007 - 2013. The study contribute to body of knowledge on the determinants of SMEs cash holdings by focusing on small and medium-sized entities in Nigeria on which very limited studies were conducted. In addition he study confirm some of the findings of previous scholars by testing the relationship between SMEs cash holdings with cash conversion cycle, return on assets, cash conversion efficiency, board size, firm size, sales growth, leverage and firm age. Further, the study links the three theoretical models (trade-off theory, pecking order theory and free cash flow theory) with the determinants of SMEs cash holdings. Thus, the study concludes that cash conversion cycle, profitability measured by return on assets, and board size are important determinants of SMEs cash holdings in Nigeria. Other determinants establishes by the study are firm size, sales growth, leverage and firm age. However, cash conversion efficiency may not have a significant influence on the SMEs cash holdings in Nigeria based on the findings of the study. Similarly, the findings of the study generally support the view that trade-off theory, pecking order theory and free cash flow theory play an important role in explaining the determinants of SMEs cash holdings in Nigeria. This study is limited to a sample of non-financial and non-services Nigerian SMEs during the period 2007 to 2013. The findings of the study could only be generalized to all SMEs except those in the financial and services industries. Therefore, future studies should extend the scope of the investigation 
to include firms in the financial and services industries. Other potential determinants of firm cash holdings such as net working capital and firm's cash flows should also be investigated.

\section{References}

Abushammala, S. N. M., \& Sulaiman, J. (2014). Cash Holdings and Corporate Profitability: Some Evidences form Jordan. International Journal of Innovation and Applied Studies, 8(3), 898-907.

Abuzayed, B. (2012). Working capital management and firms' performance in emerging markets: the case of Jordan. International Journal of Managerial Finance, 8(2), 155-179. doi.10.1108/17439131211216620

Afza, T., \& Adnan, S. (2007). Determinants of corporate cash holdings: A case study of Pakistan. Proceedings of Singapore Economic Review Conference (SERC) 2007, August 01-04 organised by Singapore Economics Review and the University of Manchester (Brooks World Poverty Institute), Singapore 164 - 165 [online] copy.

Anagnostopoulou, S. (2012). Cash Holdings: Determining Factors and Impact on Future Operating Performance for Listed vs. Unlisted Firms. Centerforpbbefr.Rutgers.Edu, (November 2012), 150.

Anjum, S., \& Malik, Q. (2013). Determinants of corporate liquidity: An analysis of cash holdings. Journal of Business and Management, 7(2), 94-100.

Arunkumar, O. N., \& Radharamanan, T. (2012). Analysis of Effects of Working Capital Management on Corporate Profitability of Indian Manufacturing Firms. Internationational Journal of Business Insights and Transformation, 5(1), 71 - 77.

Autukaite, R., \& Molay, E. (2014). Cash Holdings , Working Capital and Firm Value : Evidence From France, 30(July), 1-22.

Baños-Caballero, S., García-Teruel, P. J., \& Martínez-Solano, P. (2012). How does working capital management affect the profitability of Spanish SMEs? Small Business Economics, 39(2), $517-$ 529. doi.org/10.1007/s11187-011-9317-8

Bigelli, M., \& Sánchez-Vidal, J. (2012). Cash holdings in private firms. Journal of Banking \& Finance. 36(1), 26-35.

Block, J., \& Lau, J. (2012). Corporate Cash Holdings and their Implications on Firm Value in Family and Founder Firms. Available at SSRN 2000175, 1-40.

Bokpin, G. a., Isshaq, Z., \& Aboagye-Otchere, F. (2011). Ownership structure, corporate governance and corporate liquidity policy: Evidence from the Ghana Stock Exchange. Journal of Financial Economic Policy, 3(3), 262-279. doi.org/10.1108/17576381111152236

Fazzari, S. . and P. (1993). Working Capital and Fixed Investment: New Evidence on Financing Constraints on JSTOR.

Ferreira, M., \& Vilela, A. (2004). Why do firms hold cash? Evidence from EMU countries. European Financial Management. Retrieved from http://onlinelibrary.wiley.com/doi/10.1111/j.13547798.2004.00251.x/full

Field, A. (2013). Discovering statistics using IBM SPSS statistics. Retrieved from https://books.google.com.my/books?hl=en\&lr=\&id=c0Wk9IuBmAoC\&oi=fnd\&pg=PP2\&dq=Fi eld,+A.+(2005).+Discovering+Statistics+Using+SPSS+for+Windows\&ots=LaCjKN_BI\&sig=sL8SmhB-J5O4A9Z8qoCL2mCvUJw

García-Teruel, P. J., \& Martínez-Solano, P. (2008). On the determinants of SME cash holdings: Evidence from Spain. Journal of Business Finance and Accounting, 35(1-2), 127-149. http://doi.org/10.1111/j.1468-5957.2007.02022.x

Gill, A. S., \& Biger, N. (2013). The impact of corporate governance on working capital management efficiency of American manufacturing firms. Managerial Finance, 39(2), 116-132. http://doi.org/http://dx.doi.org/10.1108/03074351311293981

Gill, A., \& Shah, C. (2012). Determinants of Corporate Cash Holdings: Evidence from Canada. 
International Journal of Economics and Finance, 4(1), 70-79. http://doi.org/10.5539/ijef.v4n1p70

Gill, A., \& Shah, C. (2012). Determinants of corporate cash holdings: Evidence from Canada. International Journal of Economics and Finance. Retrieved from http://www.ccsenet.org/journal/index.php/ijef/article/view/13673

Hair, J. F., Hult, J. G. T. M., Ringle, C. M., \& Sarstedt, M. (2014). Partial Least Squares Structural Equation Modeling ( Pls-Sem ).

Howorth, C., Peel, M., \& Wilson, N. (2000). Late payment and credit management in the small firms sector: some empirical evidence. http://doi.org/10.1177/0266242600182001

Jensen, M. C. (1993). the Modern Industrial Revolution, Exit , and the Failure of Internal Control Systems the Failure of Internal Control Systems. Journal of Finance, 48(3), 831-880. http://doi.org/10.1111/j.1540-6261.1993.tb04022.x

Jensen, M., \& Meckling, W. (1979). Theory of the firm: Managerial behavior, agency costs, and ownership structure. Retrieved from http://link.springer.com/chapter/10.1007/978-94-009-92573_8

Kariuki, S., Namusonge, G., \& Orwa, G. (2015). DETERMINANTS OF CORPORATE CASH HOLDINGS: EVIDENCE FROM PRIVATE MANUFACTURING FIRMS IN KENYA. International Journal of Advanced Research in Managment and Social Sciences, 4(6), 15 - 33. Retrieved from http://garph.co.uk/IJARMSS/June2015/2.pdf

Kumar, N., \& Singh, J. (2013). Effect of board size and promoter ownership on firm value: some empirical findings from India. ... : The International Journal of Business in .... Retrieved from http://www.emeraldinsight.com/doi/pdf/10.1108/14720701311302431

Mathuva, D. M. (2010). The Influence of Working Capital Management Components on Corporate Profitability: A Survey on Kenyan Listed Firms. Research Journal of Business Management. http://doi.org/10.3923/rjbm.2010.1.11

Myers, S. C., \& Majluf, N. S. (1984). Corporate financing and investment decisions when firms have information that investors do not have. Journal of Financial Economics, 13(2), 187-221. http://doi.org/10.1016/0304-405X(84)90023-0

Ogunpide, L., Ogunpide, S., \& Ajao, S. (2012). Cash Holding and Firm Characteristics: Evidence From Nigerian Emerging Market. Journal of Business, Economics \& Finance, 1(2), 45-58.

Okpara, J. O. (2011). Factors constraining the growth and survival of SMEs in Nigeria: Implications for poverty alleviation. Management Research Review, 34(2), 156-171. doi.10.1108/01409171111102786

Opler, T., Pinkowitz, L., Stulz, R., \& Williamson, R. (2001). Corporate cash holdings. Journal of Applied Corporate Finance, 14(1), 55-66. http://doi.org/10.1111/j.1745-6622.2001.tb00320.x

Ozkan, A., \& Ozkan, N. (2004). Corporate cash holdings: An empirical investigation of UK companies. Journal of Banking and Finance, 28(9), 2103-2134. http://doi.org/10.1016/j.jbankfin.2003.08.003

Steijvers, T., \& Niskanen, M. (2013). The determinants of cash holdings in private family firms. Accounting and Finance, 53(2), 537-560. http://doi.org/10.1111/j.1467-629X.2012.00467.x

Tsagem, M. M. (2014). Impact of Working Capital Management and Corporate Governance on the Profitability of Small and Medium-Sized Entities in Nigeria : A Proposed Model, (2), 53-65.

Tsagem, M. M., Aripin, N., \& Ishak, R. (2015). Impact of Working Capital Management , Ownership Structure and Board Size on the Profitability of Small and Medium-Sized Entities in Nigeria. International Journal of Economics and Financial Issues, 5(Special Issue), 77-83.

Ujunwa, A. (2012). Board characteristics and the financial performance of Nigerian quoted firms. Corporate Governance, 12(5), 656-674. http://doi.org/10.1108/14720701211275587

Wai, Wong Ying and Zhun, Y. (2013). The Effect of Corporate Governance on Cash Holdings: Evidence from Hong Kong, (April). 